\title{
THE INFLUENCE OF TEACHING MODELS AND REASONING ABILITY TOWARD WRITING SKILL
}

\author{
M. Syahrun Effendi ${ }^{1,}$ Zainal Rafli ${ }^{2}$, Aceng Rahmat ${ }^{3}$ \\ STKIP-PGRI Lubuk-Linggau ${ }^{1}$, Universitas Negeri Jakarta ${ }^{2}$, Universitas Negeri Jakarta ${ }^{3}$ \\ em.syahrun@yahoo.com ${ }^{1}$, zainal.rafli@unj.ac.id ${ }^{2}$, aceng.rahmat@unj.ac.id ${ }^{2}$
}

\begin{abstract}
The purpose of this experimental research is to figure out the influence of teaching model and reasoning ability toward students' writing skill. The research was conducted at state elementary School 9 of Tanjung Batu - Ogan Ilir South Sumatra. The results show that: (1) students' writing skill using Discovery Learning model is higher than the ones use Guided Learning model; (2) There is an interaction effect between the teaching model and reasoning ability toward writing skill, and (3) students' writing skill with high reasoning ability and using Discovery Learning model is higher than the students using Guided Learning model, and (4) the level of students' writing skill with low reasoning ability and using Discovery Learning model is less than the ones use Guided Learning.
\end{abstract}

\section{Keywords: Discovery Learning, Guided Learning, Reasoning Ability, Writing Skill}

Writing skill is one of the most prominent aspect in language ability and closely related to other language skills, such as listening, speaking and reading. Those four language skills are complementary and interrelated each other. For language learners, writing skill can be a key to be successful in either academic life or working life. In getting jobs, people are required to be able to write properly; for example writing application letter. For these reasons, writing skill is then as one of the required ability in teaching at elementary schools; beside reading ability and numeracy ability. It can be stated that teaching writing for elementary education is necessary and important.

However, teaching writing at elementary faces many challenges concerning to writing performance achieved by the students. As a result, teachers need to be more attentive in selecting and applying methods or model in teaching writing. It is because models or methods of teaching plays an important factor in improving the process and the result of teaching (Slameto, 2010:110).

Based on Curriculum 2013, teaching at elementary schools applies thematic integrative teaching approach in which combines themes as a center of subject; one theme for several subjects in several meeting sessions. To achieve targeted competences in curriculum, discovery learning is used in the classroom. Discovery learning includes the process of observing, questioning, collecting, associating, and communicating information (The Ministry of Education and Culture, 2014:28).

Moreover, this present research implemented two teaching models, discovery learning and guided learning, in teaching writing skill. Discovery learning is intentionally designed to enhance students' participation and self-discovery in getting needed information to achieve learning objectives. On the other hand, guided learning is a model of teaching which uses guided discovery in finding information. Using this model, teachers mostly present experiences and lead the students in forming a set of concepts to be understood. These two models are expected solving the problems and constraints in teaching writing at elementary schools, particularly SD Rintisan Pelaksanaan Kurikulum 2013 (A Pioneer in Implementing Curriculum 2013) Ogan Ilir, South Sumatera. 
In addition to models of teaching, students' reasoning ability may influence their writing performance. Each student has different ability in reasoning things. One has high level of reasoning ability; meanwhile, the others have low levels. With this difference, it can be presumably stated that reasoning ability gives effect toward students' writing skill. Therefore, the teachers are able to select and apply appropriate models of teaching in which are proper and meet students' levels of reasoning ability to achieve higher writing skills.

Regarding to the discussions above, this current research addresses to answer the following questions: (1) Is there any different level of writing skill between students taught by Discovery Learning and by Guided Learning?; (2) Is there any interactive effect between models of teaching (Discovery Learning and Guided Learning) and reasoning ability toward writing skill?; (3) Is there any different level of writing skill upon the students with high level of reasoning ability between teaching using Discovery Learning and Guided Learning?; (4) Is there any different level of writing skill upon the students with low level of reasoning ability between teaching using Discovery Learning and Guided Learning?

Writing is one of productive language skill, in which is activity in expressing idea, thought, and intention in written language or symbols. Writers have to master either linguistic elements or non-linguistic elements in writing a text. Those elements should be tied and united in composing a well-organized logical and coherent text. The basis in composing text is the knowledge of content, linguistic aspects and writing techniques (Akhadiah, Arsyad, dan Ridwan, 1991: 2).

Furthermore, Discovery Learning, as one of model of teaching, can be defined as a mode or way in presenting topic materials that enables students to find patterns or understanding by themselves through prior learning experiences. Materials that have to be learnt are not presented in a final form; however, the students must activate their mental before those materials understood. Discovery Learning model is intentionally designed to enhance students' participation and is oriented to the process of self-discovery on needed information or knowledge in achieving learning objectives. This activity provides the students more active in learning process while teachers has merely to be facilitators in managing and organizing the process. This kind of learning process gives positive impact on development of students' creative thinking (Suryosubroto, 2009: 178).

On the other side, according to Burden and Byrd (2003:158), Guided Learning is a model of teaching that uses guided discovery approach. In this model, students are guided to do various experimental activities so that they could find targeted results. They are able to understand scientific concepts in accordance with their intellectual readiness. As a result, teachers need to explore their basic knowledge and lead them to understand new concepts in achieving learning objectives. The table below shows the comparison concepts of Discovery Learning and Guided Learning.

\section{NO. DISCOVERY LEARNING}

1. A condition of student oriented.

2. Teacher role as facilitator to stimulate students to be more active.

3. Students do tasks by themselves independently in allocated time.

4. The assessment based on process and product.

\section{GUIDED LEARNING}

\section{A condition of teacher oriented.}

Teacher role as resources in guiding and solving problems intensively.

Students do tasks as instructed by the teacher and under teacher' supervision in allocated time based on topic materials.

Assessment based on process, but primarily on product 
Moreover, students' writing skill is may affected by their reasoning ability. Related to reasoning ability, Suriasumantri (1993: 42-43) wrote that reasoning is thinking activity to deduce a conclusion based on observation of facts or hypotheses that is stated in either oral communication or written communication. Reasoning is a process of making conclusion of inference from evidence or proof. Then, reasoning activity results in a knowledge concerning to the process of thinking instead of feeling. The generated knowledge can be said as a valid knowledge. However, the thinking process in generating valid knowledge has different, various ways. Each thinking provides a set of criteria of truth; and then, the criteria of truth become a base on process of discovering the truth.

\section{METHODS}

This present research was carried out by experimental research design using treatment by level. Moreover, it was conducted in SD Rintisan Pelaksanaan Kurikulum 2013 at Ogan Ilir, South Sumatera. The samples were 36 Grade IV students from SDN 9 tanjung Batu in 2106/2017 academic year. The students were divided into two groups: experiment and control groups. Each group consisted of mixed-group of reasoning ability, in which was low and high level of reasoning ability. The experiment group was treated by Discovery learning; on the contrary, Guided Learning was applied on control group.

For collecting data, writing test, to gain students' writing skill, and reasoning ability test, to obtain the level of reasoning ability, were as the instruments. To meet the data requirements, normality test and homogeneity test were conducted by using Lilliefors Test and Bartlett Test. Meanwhile, for analyzing data, ANAVA statistical analysis technique using Tuckey Test was used.

\section{RESEARCH AND DISCUSSION}

This current research was to discover the influence of teaching models and reasoning ability toward writing skill at elementary schools. After collecting and analyzing data, the research results are displayed based on the research questions.

\section{Scores of Writing Skills using Discovery Learning}

Based on the obtained data, it was founded from 18 students, the highest score was 78; meanwhile, the lowest is 65 . Mean score gains 72.06 with median 72 and mode 77 , and variances was 18.29 with deviation standard 4.28. Frequency distribution table can be seen below.

Table 1. Frequency Distribution Score of Writing Skill for Students with Discovery Learning

\begin{tabular}{cccc}
\hline No & Interval Class & Absolute Frequency & Relative Frequency $(\%)$ \\
\hline 1 & $65-67$ & 4 & 22.22 \\
2 & $68-70$ & 2 & 11.11 \\
3 & $71-73$ & 4 & 22.22 \\
4 & $74-76$ & 4 & 22.22 \\
5 & $77-79$ & 4 & 22.22 \\
\hline & Total & 18 & $100 \%$ \\
\hline
\end{tabular}


From the table, it can be stated that $22.22 \%$ of students gets average scores, and $44.44 \%$ of above average. Meanwhile, the rest $33.33 \%$ scores below average. The histogram of the writing score for students using discovery learning is displayed below.

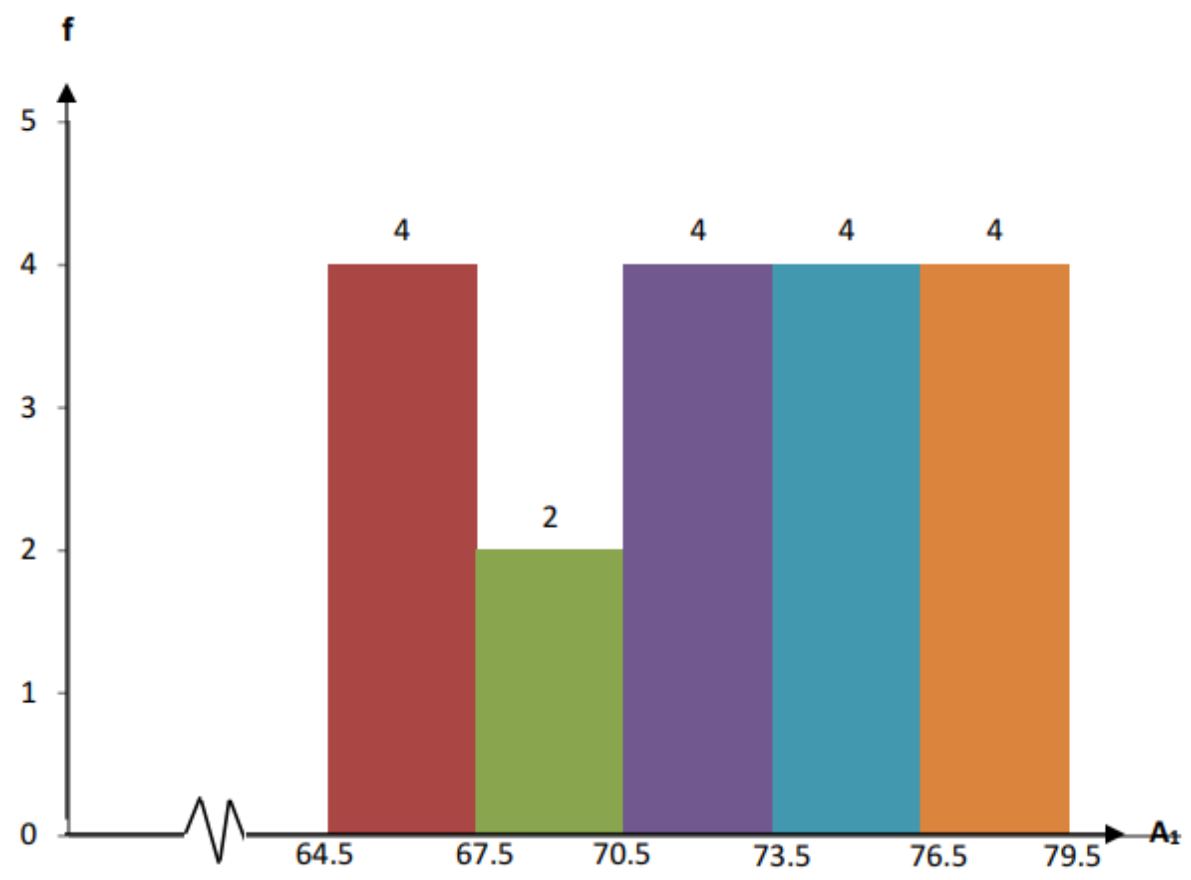

Figure 1. Histogram of of Writing Skill for Students with Discovery Learning

\section{Scores of Writing Skills using Guided Learning}

Based on the obtained data, it was founded from 18 students using Guided Learning, the highest score was 78; meanwhile, the lowest is 65 . Average score gains 70.22 with median 70.00 and mode 67 , and variances was 10.54 with deviation standard 3.25. Frequency distribution table can be seen below.

Table 2. Frequency Distribution Score of Writing Skill for Students with Guided Learning

\begin{tabular}{cccc}
\hline No & Interval Class & Absolute Frequency & Relative Frequency (\%) \\
\hline 1 & $65-67$ & 5 & 27.78 \\
2 & $68-70$ & 4 & 22.22 \\
3 & $71-73$ & 7 & 38.89 \\
4 & $74-76$ & 1 & 5.56 \\
5 & $77-79$ & 1 & 5.56 \\
\hline & Total & 18 & $100 \%$ \\
\hline
\end{tabular}

From the table, it can be said that $38.88 \%$ of students gets average scores, and $11.12 \%$ of above average. Meanwhile, the rest 50\% scores below average. The histogram of the writing score for students using discovery learning is displayed below. 


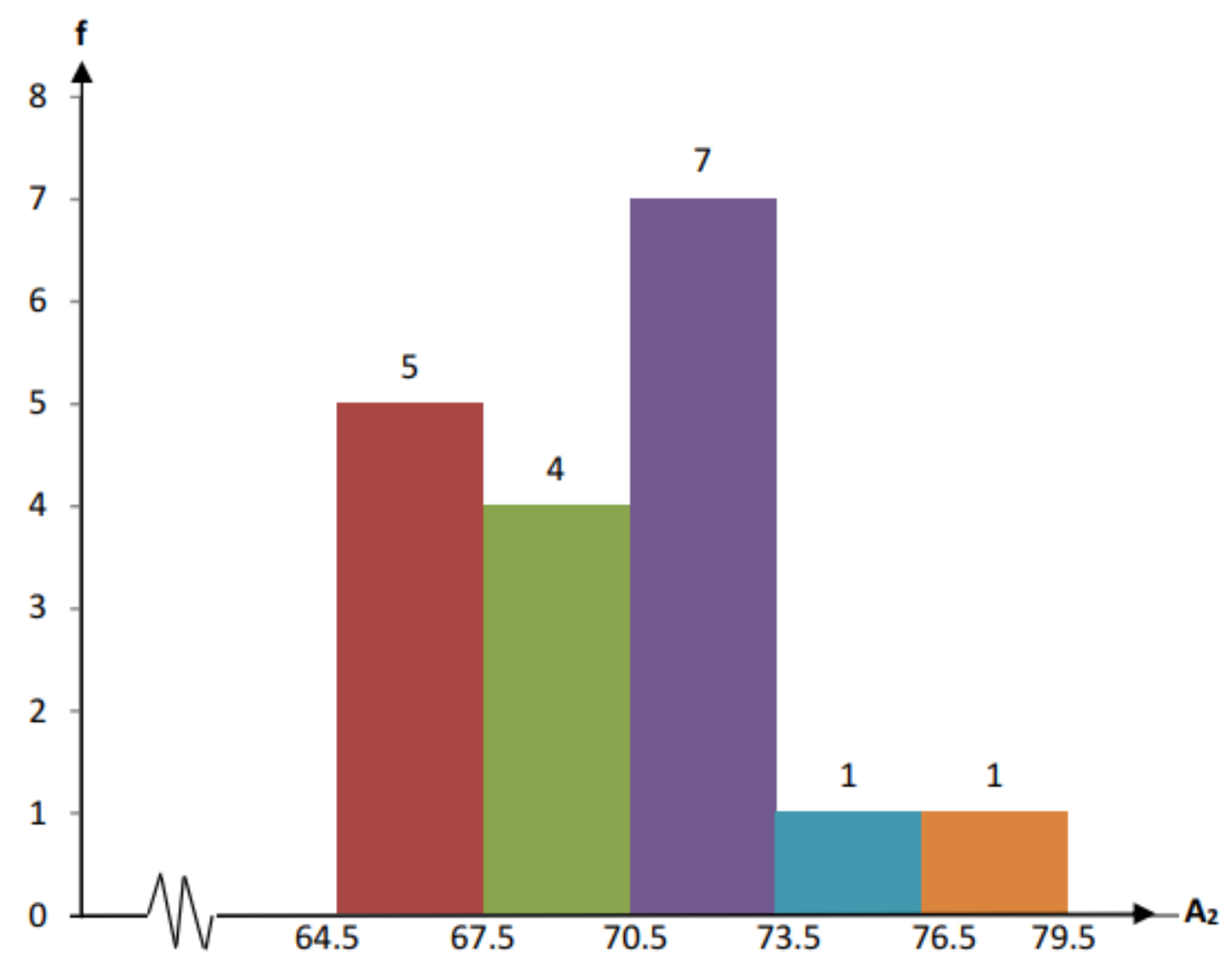

Figure 2. Histogram Score of Writing Skill for Students with Guided Learning

\section{Scores of Writing Skills for the Students with High Reasoning Ability}

From the collected data of 18 students, the highest score of writing skill was 78, and the lowest was 65 . The average score was 72 with median 72 and mode 67 . Meanhile, the variance score was 18.12 and deviation standard was 4.26. The frequency distribution table can be seen below.

Table 3. The Frequency Distribution Score of Writing Skill for Students with High Reasoning Ability

\begin{tabular}{cccc}
\hline No & Interval Class & Absolute Frequency & Relative Frequency (\%) \\
\hline 1 & $65-67$ & 4 & 22.22 \\
2 & $68-70$ & 3 & 16.67 \\
3 & $71-73$ & 3 & 16.67 \\
4 & $74-76$ & 4 & 22.22 \\
5 & $77-79$ & 4 & 22.22 \\
\hline & Total & 18 & $100 \%$ \\
\hline
\end{tabular}

From the table, it can be said that $16.67 \%$ of students gets average scores, and $44.44 \%$ of above average. Meanwhile, the rest $38.89 \%$ scores below average. The histogram of the writing score for students using discovery learning is displayed below. 


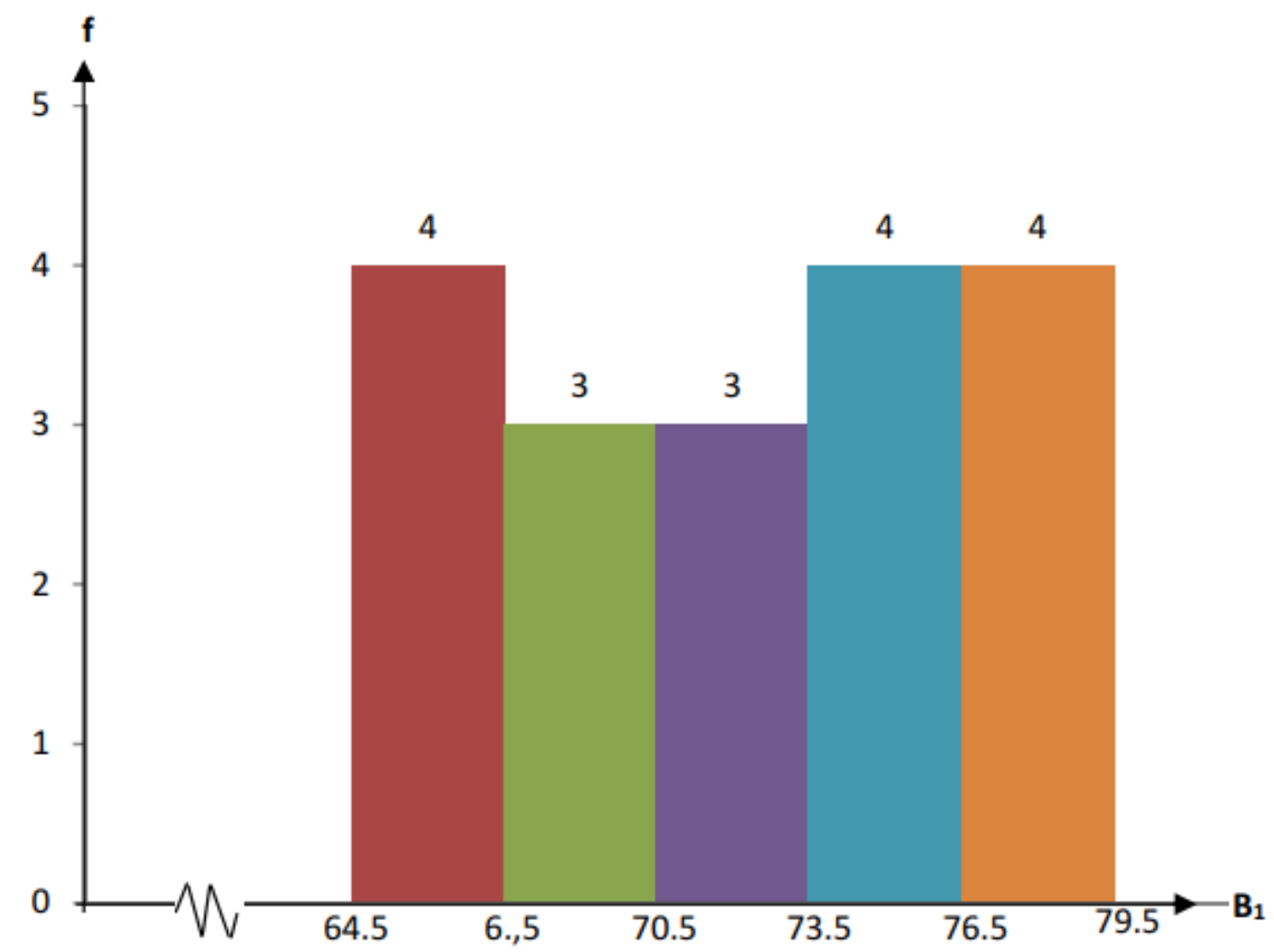

Figure 3. Histogram Score of Writing Skill for Students with High Reasoning Ability

\section{Scores of Writing Skills for the Students with Low Reasoning Ability}

From the collected data of 18 students, the highest score of writing skill was 78, and the lowest was 65 . The average score was 70.28 with median 71 and mode 67 . Meanhile, the variance score was 10.92 and deviation standard was 3.30. The frequency distribution table can be seen below.

Table 4. The Frequency Distribution of Score Writing Skill for Students with Low Reasoning Ability

\begin{tabular}{cccc}
\hline No & Interval Class & Absolute Frequency & Relative Frequency (\%) \\
\hline 1 & $65-67$ & 5 & 27.78 \\
2 & $68-70$ & 3 & 16.67 \\
3 & $71-73$ & 8 & 44.44 \\
4 & $74-76$ & 1 & 5.56 \\
5 & $77-79$ & 1 & 5.56 \\
\hline & Total & 18 & $100 \%$ \\
\hline
\end{tabular}

From the table, it can be said that $44.44 \%$ of students gets average scores, and $11.12 \%$ of above average. Meanwhile, the rest $44.45 \%$ scores below average. The histogram of the writing score for students using discovery learning is displayed below. 


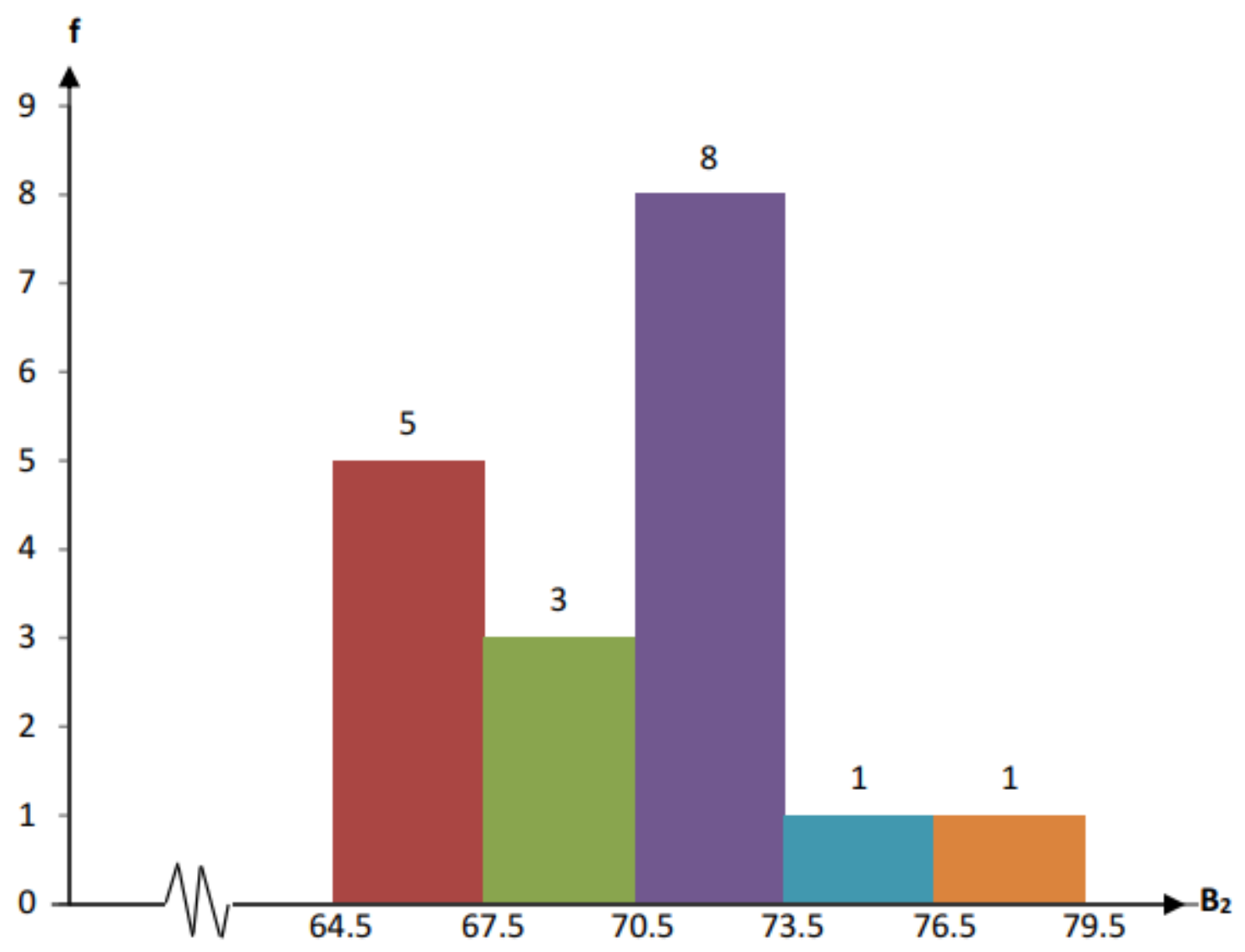

Figure 4. Histogram of Score Writing Skill for Students with Low Reasoning Ability

\section{The Score of Writing Skill for The Students with High Reasoning Ability Using Discovery Learning}

Getting data from 9 respondent students, the highest score of writing skill was 78 and the lowest was 72. Meanwhile, the average score was 75.67 with median 76 and mode 77 . Moreover, variance scores 3.5 and deviation standard was 1.87. The table of frequency distribution of writing skill for the students with high reasoning ability using guided learning can be seen below.

Table 5. The Frequency Distribution Score of Writing Skill for The Students with High Reasoning Ability using Discovery Learning

\begin{tabular}{cccc}
\hline No & Interval Class & Absolute Frequency & Relative Frequency (\%) \\
\hline 1 & $72-73$ & 1 & 11.11 \\
2 & $74-75$ & 3 & 33.33 \\
3 & $76-77$ & 4 & 44.44 \\
4 & $78-79$ & 1 & 11.11 \\
\hline & Total & 9 & $100 \%$ \\
\hline
\end{tabular}

From the table, it can be noted that $33.33 \%$ of the student has average scores. Furthermore, $55.55 \%$ of them get above average scores. The rest $11.11 \%$ gains below average. The overall scores are depicted on the histogram below. 


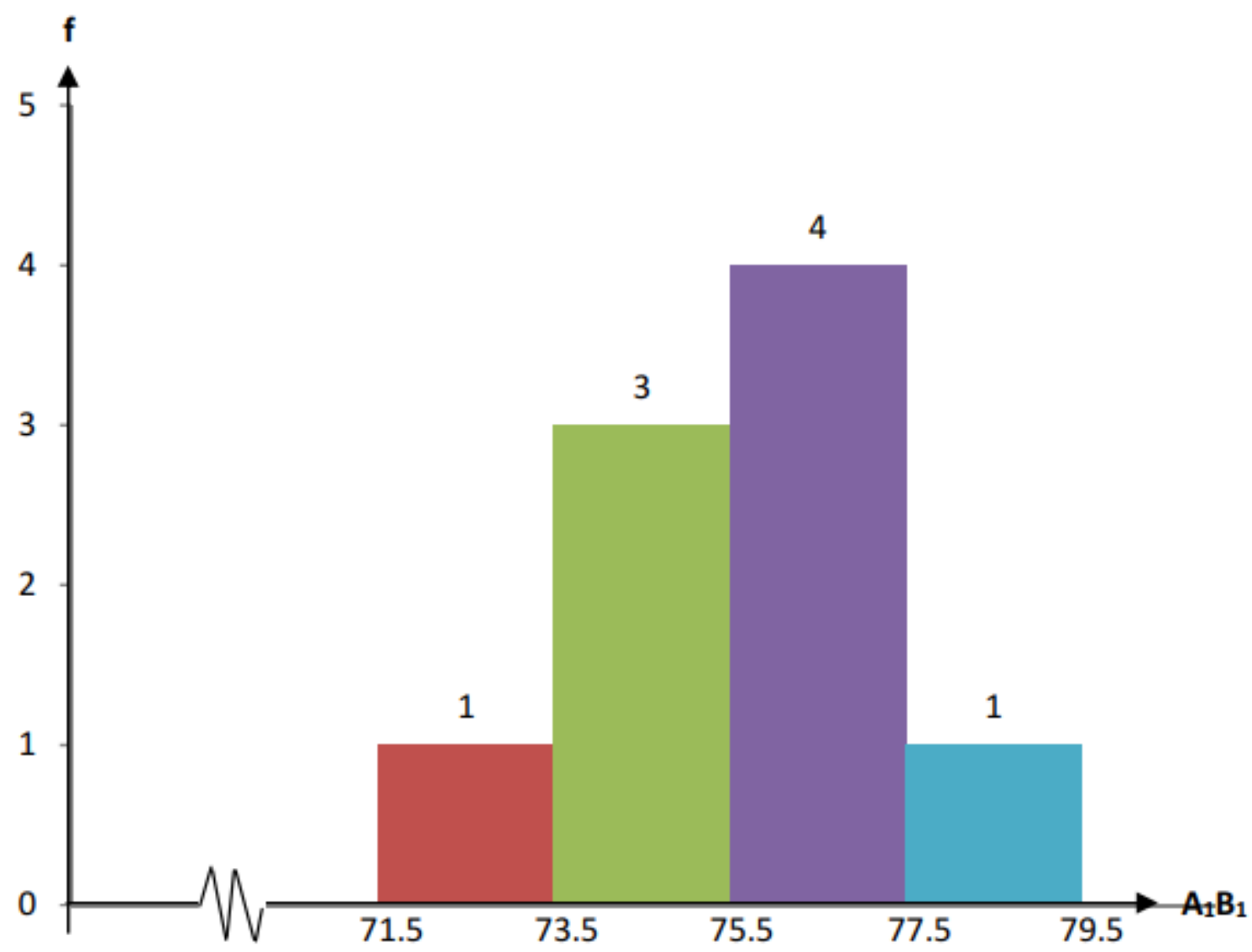

Figure 5. Histogram Score of Writing Skill for The Students with High Reasoning Ability using Discovery Learning

\section{The Score of Writing Skill for The Students with High Reasoning Ability Using Guided Learning}

Getting data from 9 respondent students, the highest score of writing skill was 72 and the lowest was 65. Meanwhile, the average score was 68.33 with median 68 and mode 67 . Moreover, variance scores 4.75 and deviation standard was 2.18 . The table of frequency distribution of writing skill for the students with high reasoning ability using guided learning can be seen below.

Table 6. The Frequency Distribution Score of Writing Skill for The Students with High Reasoning Ability using Guided Learning

\begin{tabular}{cccc}
\hline No & Interval Class & Absolute Frequency & Relative Frequency (\%) \\
\hline 1 & $65-66$ & 1 & 11.11 \\
2 & $67-68$ & 4 & 44.44 \\
3 & $69-70$ & 2 & 22.22 \\
4 & $71-72$ & 2 & 22.22 \\
\hline & Total & 9 & $100 \%$ \\
\hline
\end{tabular}

From the table, it can be noted that $44.44 \%$ of the student has average scores. Furthermore, $44.44 \%$ of them get above average scores. The rest $11.11 \%$ gains below average. The overall scores are depicted on the histogram below. 


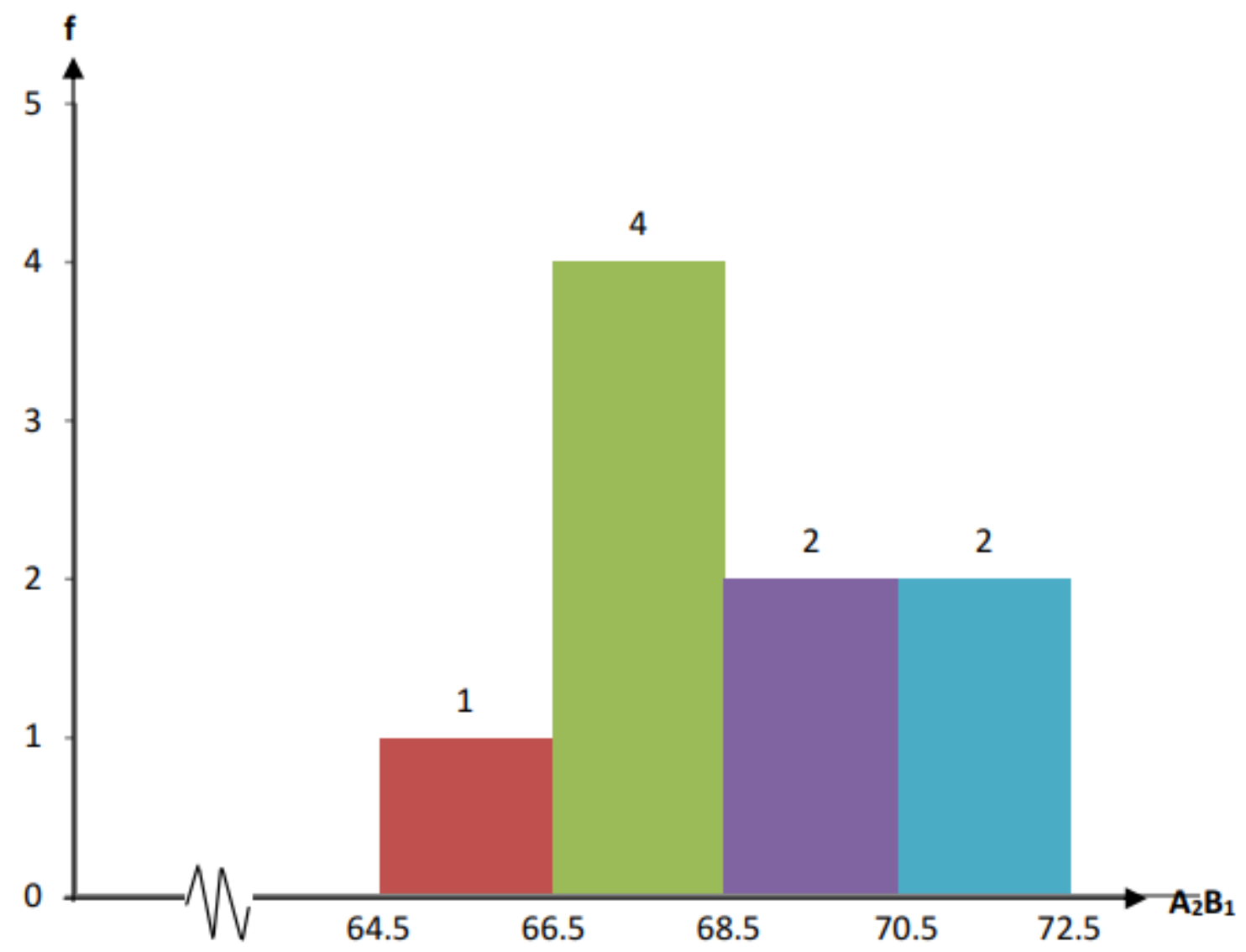

Figure 6. Histogram Score of Writing Skill for The Students with High Reasoning Ability using Guided Learning

\section{The Score of Writing Skill for The Students with Low Reasoning Ability Using Discovery Learning}

Getting data from 9 respondent students, the highest score of writing skill was 72 and the lowest was 65. Meanwhile, the average score was 68.44 with median 68 and mode 67. Moreover, variance scores 6.03 and deviation standard was 2.46. The table of frequency distribution of writing skill for the students with high reasoning ability using guided learning can be seen below.

Table 7. The Frequency Distribution Score of Writing Skill for The Students with Low Reasoning Ability using Discovery Learning

\begin{tabular}{cccc}
\hline No & Interval Class & Absolute Frequency & Relative Frequency (\%) \\
\hline 1 & $65-66$ & 2 & 22.22 \\
2 & $67-68$ & 3 & 33.33 \\
3 & $69-70$ & 1 & 11.11 \\
4 & $71-72$ & 3 & 33.33 \\
\hline & Total & 9 & $100 \%$ \\
\hline
\end{tabular}

From the table, it can be noted that $33.33 \%$ of the student has average scores. Furthermore, $44.44 \%$ of them get above average scores. The rest $22.22 \%$ gains below average. The overall scores are depicted on the histogram below. 


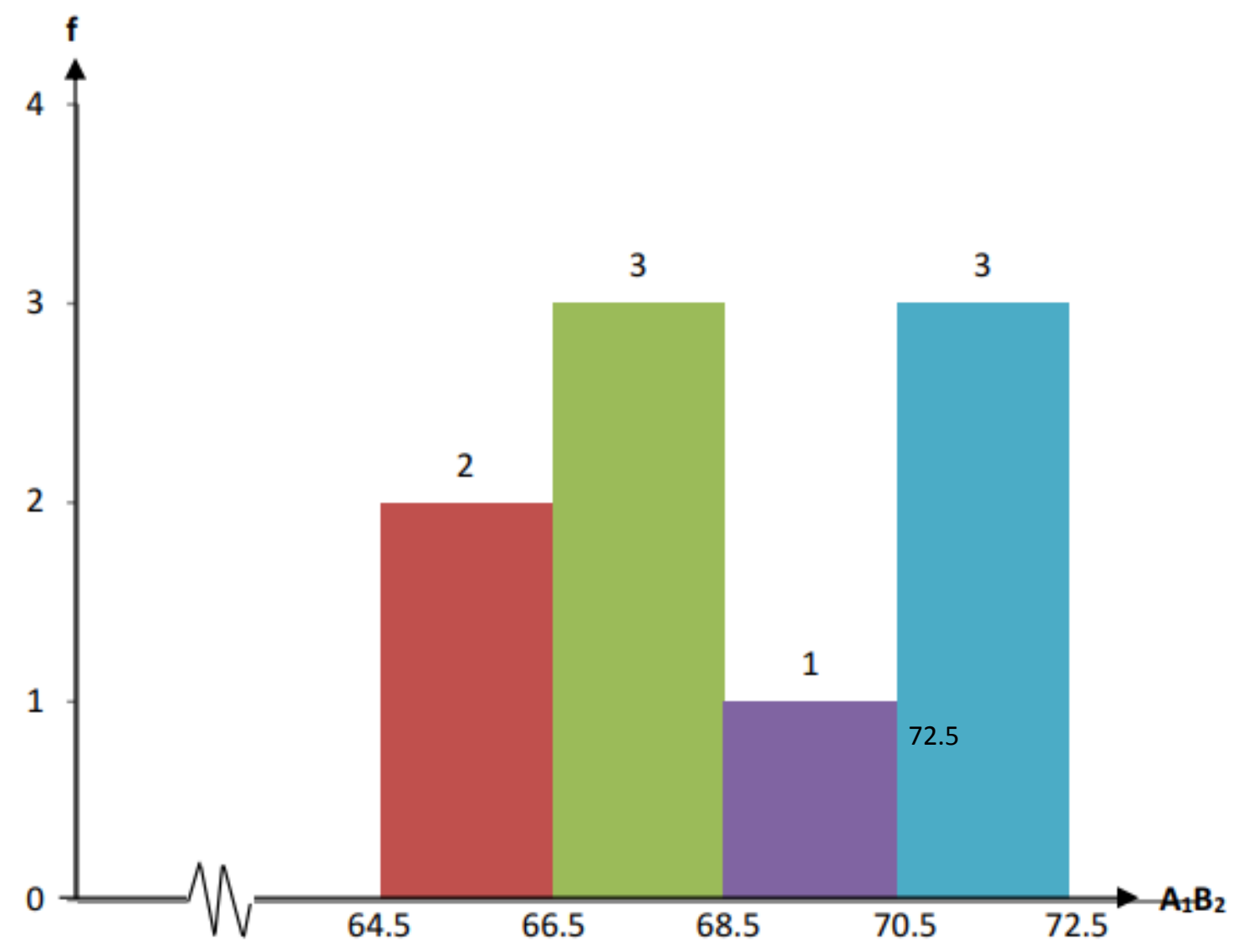

Figure 7. Histogram Score of Writing Skill for The Students with Low Reasoning Ability using Discovery Learning

\section{The Score of Writing Skill for The Students with Low Reasoning Ability Using Guided Learning}

Getting data from 9 respondent students, the highest score of writing skill was 78 and the lowest was 67. Meanwhile, the average score was 72.11 with median 72 and mode 72 . Moreover, variance scores 9.61 and deviation standard was 3.10. The table of frequency distribution of writing skill for the students with high reasoning ability using guided learning can be seen below.

Table 8. The Frequency Distribution Score of Writing Skill for The Students with Low Reasoning Ability using Guided Learning

\begin{tabular}{cccc}
\hline No & Interval Class & Absolute Frequency & Relative Frequency (\%) \\
\hline 1 & $67-69$ & 2 & 22.22 \\
2 & $70-72$ & 3 & 33.33 \\
3 & $73-75$ & 3 & 33.33 \\
4 & $76-78$ & 1 & 11.11 \\
\hline & Total & 9 & $100 \%$ \\
\hline
\end{tabular}

From the table, it can be noted that $33.33 \%$ of the student has average scores. Furthermore, $44.44 \%$ of them get above average scores. The rest $22.22 \%$ gains below average. The overall scores are depicted on the histogram below. 


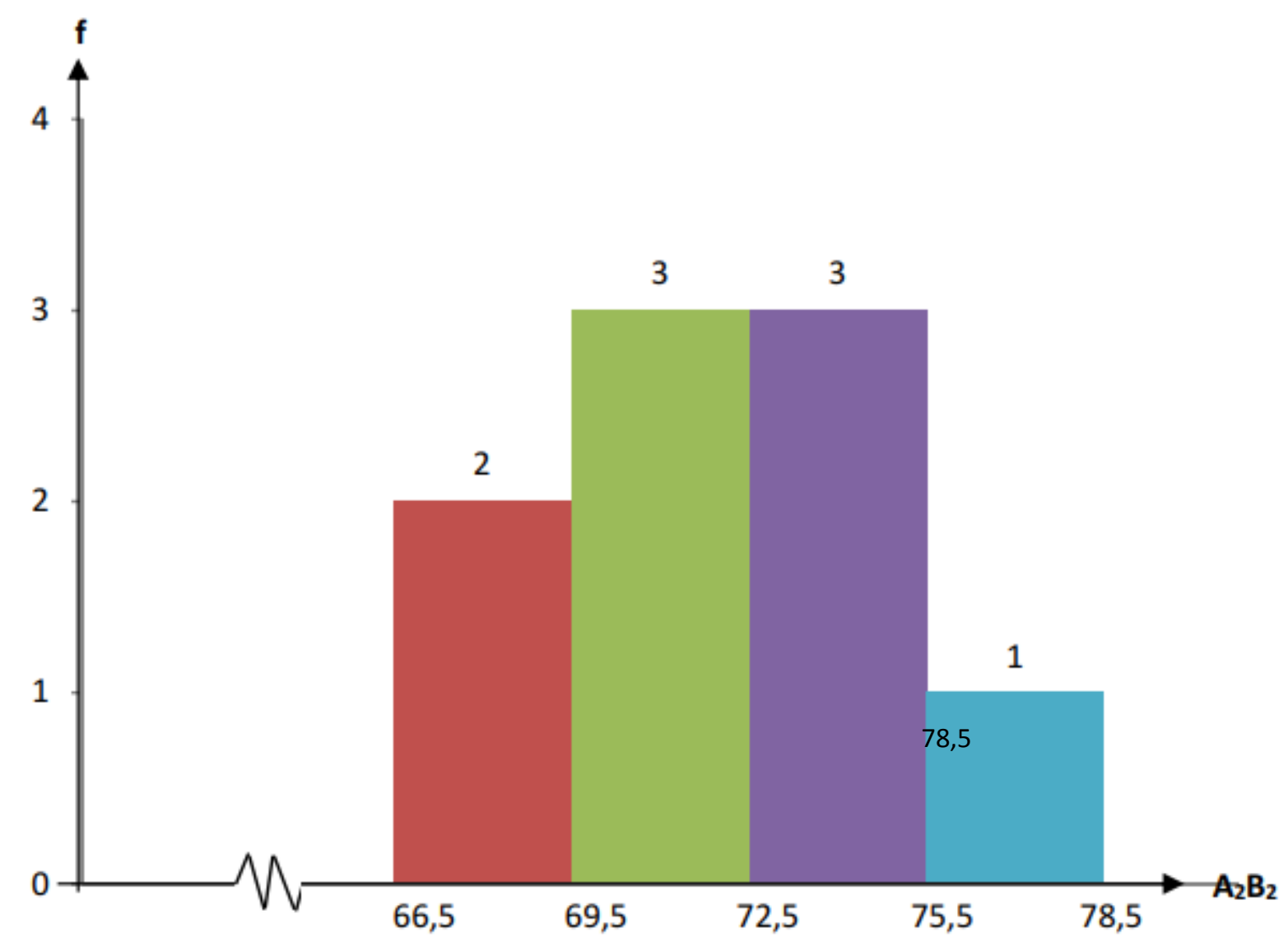

Figure 8. Histogram Score of Writing Skill for The Students with Low Reasoning Ability using Guided Learning

From the statistic calculation of ANAVA and Tuckey Test, it can be concluded that the research hypothesis can be empirically proven.

At first, two-ways variance analysis showed that $F_{\text {observe }}$ is higher than $F_{\text {table }}\left(F_{\text {observe }}=5.065>\right.$ $\left.F_{\text {table }}(0.05)=4.15\right)$. It indicates that there is a significant effect between writing skills and teaching models (discovery learning and guided learning). This is resulted from the average scores of writing skills in which discovery learning gains 72.06 and guided learning scores 70.22.

Secondly, the result of two-ways variance analysis showed that $\mathrm{F}_{\text {observe }}$ of interaction between teaching models and reasoning ability is higher than $F_{\text {table }}\left(F_{\text {observe }}=45,596>F_{\text {table }(0,01)}=7,50\right)$. As a result, based on Tuckey Test of two experimental cells, it can be drawn a conclusion that there is the significant interaction effect of teaching models and reasoning ability toward writing skill.

Moreover, at the third calculation, based on Tuckey test on students' scores of writings kill with high reasoning ability, $\mathrm{Q}_{\text {observe }}(9,06)$ is higher than $\mathrm{Q}_{\text {table }}(0,01)(5,96)$. The finding shows that there are different scores of writing skill for the students with high reasoning ability using discovery learning from those who are using guided learning. The students' scores using discovery learning with high reasoning ability are higher than those who are using guided learning.

At last, based on Tuckey Test on the scores of writing skill for the students with low reasoning ability, the value of $\mathrm{Q}_{\text {observe }}(4,53)$ is higher than $\mathrm{Q}_{\text {table }}(0,05)(4,42)$. It indicates that there is difference of students' scores of writing skill with low reasoning ability using discovery learning and those who apply guided learning. Therefore, it can be stated that the average scores of students' writing skill with low reasoning ability using discovery learning is lower than those who apply guided learning. 


\section{CONCLUSION}

Based on statistical calculation, it can be drawn some conclusions: (1) students' scores of writing skill using discovery learning is higher than those who conduct guided learning; (2) there is an interactive effect between teaching models and reasoning ability toward writing skill; (3) students' scores of writing skill with high reasoning ability using discovery learning are higher than those who apply guided learning; and (4) the students' scores of writing skill with low reasoning ability using discovery learning are lower than those who use guided learning. Furthermore, the research findings give some implications to the teaching writing at elementary schools particularly grade IV. At first, active contribution and participation from both teachers and students are important to lead in effective teaching and learning writing. And then, several attempts to enhance reasoning ability is necessary since it gives effect on writing skill. The third, the teachers are expected to be more creative in selecting and choosing models of teaching particularly in teaching writing for grade IV. For students with high reasoning ability, discovery learning is more appropriate and suitable. Meanwhile, guided learning is more effective for students with low reasoning ability.

\section{REFERENCES}

Akhadiah, Sabarti, Arsyad, Maidar, Ridwan, Sakura. Pembinaan Kemampuan Menulis Bahasa Indonesia. Jakarta: Erlangga, 1991.

B, Suryosubroto. Proses Belajar Mengajar di Sekolah. Jakarta: Rineka Cipta, 2009. Brown, H. Douglas. Principles of language learning and Teaching, Fifth Edition. USA: Pearson Education, 2006.

Burden, R. P., \& Byrd, M. D. Methods for Effective Teaching (3rd ed.).Boston: Pearson Education, 2003.

Emzir. Metodologi Penelitian Pendidikan Kuantitatif dan Kualitatif. Jakarta: PT Raja Grafindo Persada, 2012.

Kementerian Pendidikan dan Kebudayaan. Materi Pelatihan Guru Implementasi Kurikulum 2013 Tahun 2014 Jakarta: Badan PSDMPK - PMP, 2014.

Nanang, Hanafiah dan Suhada, Cucu. Konsep Strategi Pembelajaran. Bandung: Refika Aditama, 2009.

Slameto. Belajar dan Faktor-Faktor yang Mempengaruhinya. Jakarta: Rineka Cipta, 2010.

Suriasumantri, Jujun S. Filsafat Ilmu: Sebuah Pengantar. Jakarta: Pustaka Sinar Harapan. 1993. 